\title{
Comprehensive genetic assessment of a functional TLR9 promoter polymorphism: no replicable association with asthma or asthma-related phenotypes
}

\author{
Nancy E Lange ${ }^{1,2^{*}}$, Xiaobo Zhou ${ }^{1,2}$, Jessica Lasky-Su', Blanca E Himes ${ }^{1}$, Ross Lazarus ${ }^{1}$, Manuel Soto-Quirós ${ }^{3}$, \\ Lydiana Avila ${ }^{3}$, Juan C Celedón ${ }^{4}$, Catherine M Hawrylowicz ${ }^{5}$, Benjamin A Raby ${ }^{1,2}$, Augusto A Litonjua ${ }^{1,2}$
}

\begin{abstract}
Background: Prior studies suggest a role for a variant (rs5743836) in the promoter of toll-like receptor 9 (TLR9) in asthma and other inflammatory diseases. We performed detailed genetic association studies of the functional variant rs5743836 with asthma susceptibility and asthma-related phenotypes in three independent cohorts.

Methods: rs5743836 was genotyped in two family-based cohorts of children with asthma and a case-control study of adult asthmatics. Association analyses were performed using chi square, family-based and population-based testing. A luciferase assay was performed to investigate whether rs5743836 genotype influences TLR9 promoter activity.

Results: Contrary to prior reports, rs5743836 was not associated with asthma in any of the three cohorts. Marginally significant associations were found with $\mathrm{FEV}_{1}$ and FVC $(p=0.003$ and $p=0.008$, respectively) in one of the family-based cohorts, but these associations were not significant after correcting for multiple comparisons. Higher promoter activity of the CC genotype was demonstrated by luciferase assay, confirming the functional importance of this variant.
\end{abstract}

Conclusion: Although rs5743836 confers regulatory effects on TLR9 transcription, this variant does not appear to be an important asthma-susceptibility locus.

\section{Background}

Asthma is a public health problem of considerable importance with over 300 million people affected worldwide [1]. Asthma is likely due to genetic and environmental determinants that are poorly understood. Although primarily a disorder resulting from TH2 cell mediated inflammation, significant interest is developing in investigating innate immunity in the search to understand the pathogenesis of this disease [2].

Toll-like receptors (TLRs) are evolutionarily conserved components of the innate immune system that act to directly recognize pathogen-derived elements, including

\footnotetext{
* Correspondence: renal@channing.harvard.edu

'Channing Laboratory, Brigham and Women's Hospital and Harvard Medical School, 181 Longwood Avenue, Boston, MA, 02115, USA

Full list of author information is available at the end of the article
}

viral and bacterial DNA, lipopolysaccharides, and proteoglycans. They provide a crucial link between the recognition of pathogens by the innate immune system and subsequent activation of adaptive immunity, inducing maturation of antigen presenting cells and differentiation of T cells. TLR9 is expressed in plasmacytoid dendritic cells, B cells, CD3+CD4+ T cells and pulmonary epithelial cells [3], and recognizes bacterial unmethylated cytosine-guanine dinucleotide $(\mathrm{CpG})$ motifs and viral antigens [4]. When activated it leads to maturation of dendritic cells and release of pro-inflammatory TH1 cytokines such as IL-6, IL-12, TNF, IFN- $\gamma$ and IFN- $\alpha$. It can also be counter-regulatory to the induction of $\mathrm{T}$ regulatory cells (Tregs) and release of the anti-inflammatory cytokine IL-10.

\section{C) Biomed Central}

(C) 2011 Lange et al; licensee BioMed Central Ltd. This is an Open Access article distributed under the terms of the Creative Commons Attribution License (http://creativecommons.org/licenses/by/2.0), which permits unrestricted use, distribution, and reproduction in any medium, provided the original work is properly cited. 
Our group and others have previously reported an association between a single nucleotide polymorphism (SNP) in the promoter region of TLR9 (rs5743836 or $-1237 \mathrm{C} / \mathrm{T}$ ) and asthma in European American adults [5] and Tunisian children [6]. Other studies have shown associations with other inflammatory diseases such as allergic bronchopulmonary aspergillosis (ABPA) [7], atopic eczema [8], and inflammatory bowel disease (IBD) [9-11]. The observed associations between rs5743836 and various immune-mediated diseases in different populations point to the possibility that this SNP may be functional and potentially involved in immune system regulation. Of interest, an interaction between TLR9 and vitamin $\mathrm{D}$ has been implicated in the induction of Tregs that produce IL-10 [12], an anti-inflammatory cytokine with potent inhibitory effects on TH1 and TH2 responses[13].

Given previous findings, we sought to investigate the possible association between SNP rs5743836 and asthma in three different cohorts of asthmatics: the Childhood Asthma Management Program (CAMP), the Genetics of Asthma in Costa Rica study (Costa Rica), and the Informatics for Integrating Biology to the Bedside (i2b2) Crimson Asthma Project (iCAP). CAMP is a wellcharacterized cohort of children from North America with mild to moderate asthma in whom we have multiple measures of lung function as well as data on exacerbations, atopy and vitamin D levels. Because of the extensive phenotyping in CAMP, we decided to probe more deeply in this cohort by investigating possible associations with asthma-related quantitative phenotypes, and to assess for interaction with vitamin D. In addition, we performed functional studies in cell cultures to determine potential functional significance of this SNP.

\section{Methods}

\section{Population and phenotyping data} CAMP cohort

The Childhood Asthma Management program (CAMP) is a multi-center, randomized, double-masked, placebocontrolled clinical trial designed to investigate the longterm effects of inhaled anti-inflammatory medications in children with mild to moderate asthma $[14,15]$. Of the 1041 children enrolled in the original clinical trial, DNA samples were obtained from 968 participating children and 1518 of their parents. Due to the small sample size of other ethnic groups, this analysis was restricted to 711 self-reported non-Hispanic white probands ( $\mathrm{n}=$ $711)$ and available parents $(n=638$ complete trios). A diagnosis of asthma was based on methacholine hyperreactivity $\left(\mathrm{PC}_{20} \leq 12.5 \mathrm{gm} / \mathrm{ml}\right)$ and one or more the following criteria for at least 6 months in the year before recruitment: 1) asthma symptoms at least 2 times per week, 2) at least 2 uses per week of an inhaled bronchodilator, and 3) daily asthma medication. Spirometry was performed according to American Thoracic Society (ATS) recommendations [16] using a volume displacement spirometer. Vitamin D levels (25-hydroxyvitamin D) from serum collected prior to treatment randomization and at 44 months post-randomization were measured using a radionimmunoassay method in Dr. Bruce Hollis' laboratory at the Medical University of South Carolina $[17,18]$. The Institutional Review Board of each of the CAMP study centers approved this study. Informed assent and consent were obtained from all study participants and their parents to collect DNA for genetic studies.

\section{Costa Rica cohort}

Participants in the Costa Rica study included 616 children ages 6-14 years with asthma (defined as physiciandiagnosed asthma and $\geq 2$ respiratory symptoms or recurrent asthma attacks in the past year) recruited between February 2001 and March 2005, as previously described [19]. This population is a genetic isolate of mixed Spanish and Amerindian descent with one of the world's highest rates of asthma (27.4\% of children aged 6-7 years) [20]. The study was approved by the Institutional Review Boards of the Hospital Nacionál de Niños (San Jose, Costa Rica) and Brigham and Women's Hospital (Boston, MA, USA). After obtaining written informed consent from the parents of participating children, each participant completed a modified version of the questionnaire used in the Collaborative Study on the Genetics of Asthma [21], translated into Spanish. Each subject performed baseline spirometry according to ATS recommendations [16], using a Collins Survey Tach Spirometer (Warren Collins, Braintree, MA, USA). Following baseline spirometry, subjects received $200 \mu \mathrm{g}$ of albuterol. Spirometry was repeated after 15 minutes.

\section{iCAP cohort}

The i2b2 Crimson Asthma Project (iCAP) consists of Partners Healthcare System, Inc. (Boston, MA) patients who were selected based on extracted de-identified electronic medical record (EMR) data and whose DNA was obtained via discarded clinical samples. The collection and study of this data was approved by the Institutional Review Board of Partners Healthcare System. Asthmatic and non-asthmatic Partners Healthcare patients were identified on the basis of International Classification of Diseases, Ninth Revision (ICD-9) codes for asthma (i.e. those beginning with 493) [22,23]. DNA was obtained from discarded clinical blood samples via the Crimson Project http://www.crimsonproject.org, which identifies discarded Partners Healthcare clinical samples using medical record numbers obtained from the EMR query. For this study, to further ensure that cases truly had asthma, cases $(n=223)$ were defined as those patients whose EMRs contained an asthma ICD-9 code and 
whose medication history included usage of at least one beta-agonist or inhaled corticosteroid. Controls $(\mathrm{n}=$ 858) were selected as those patients who had been seen in the three years prior to blood collection in at least one of over 850 outpatient clinics but did not have any asthma ICD-9 codes. All patients are white. Using a panel of 187 intergenic SNPs selected randomly throughout the genome[24], and a set of 248 ancestry informative markers[25], we evaluated this cohort for evidence of population stratification. The random panel of 187 SNPs had an association $\chi^{2} 187 \mathrm{df}=168.7$, corresponding to a p-value of 0.83 . Repeat association testing with adjustment for EIGENSTRAT-derived principal components[26] yielded similar results to the unadjusted results $\left(\mathrm{r}^{2}=0.95\right.$ between corrected and uncorrected association statistics), confirming no significant evidence of population stratification in the iCAP cohort.

\section{Genotyping and Quality Control}

rs5743836 genotyping was performed using a custom design TaqMan $5^{\prime} \rightarrow 3^{\prime}$ assay (ABI, Foster City, California) with the following sequences: Forward primer: GCCTTGGGATGTGCTGTTC; Reverse primer: CAGAGACATAATGGAGGCAAAGGA; VIC Probe: CCTGAA AACTCCC; FAM Probe: CTGGAAACTCCC. The PCR profile consisted of an initial denaturation step at $95^{\circ} \mathrm{C}$ for $10 \mathrm{~min}$ followed by 40 amplification cycles at $95^{\circ} \mathrm{C}$ for $30 \mathrm{~s}$ each. For the PCR reaction, ABI TaqMan Universal PCR Master Mix was used with 6.25 ng of DNA per sample. ABI 7900 Prism was used for imaging.

TLR9 mRNA expression data was extracted from genome-wide gene expression microarray profiles (HumanRef8 v2 BeadChip (Illumina, San Diego, CA)) derived from peripheral blood CD4+ lymphocyte RNA samples in a subset of 200 CAMP participants, as previously reported[27]. TLR9 is assayed on the HumanRef8 v2 array with a 50-mer oligonucleotide with sequence 5'CAGGGACAACCACCACTTCTATAACCG-

GAACTTCTGC CAGGGACCCACGG-3', which maps to the terminal coding sequence of the TLR9 reference sequence (NM_017442).

\section{Statistical Analysis}

Family based association testing (FBAT) was performed using PBAT as implemented in HelixTree version 6.4.3 (Golden Helix, Bozeman, Mont)[28]. TLR9-by-vitamin D level interactions were tested using the family-based association tests of interaction (FBATIs) implemented in PBAT[29]. PLINK[30] was utilized for population-based association testing and to derive the transmitted to untransmitted ratios. PLINK was also used for allelic association testing $\left(\chi^{2}\right)$ in the case-control study (iCAP). All analyses were performed assuming an additive genetic model.
In CAMP, tests of association with baseline lung function were adjusted for age, sex, and height. Tests of association with all other baseline outcomes were adjusted for age and sex, and all tests for outcomes at the 4 year follow-up time point were also adjusted for treatment group (inhaled steroids vs. placebo or nedocromil). In the population-based analyses in CAMP, we adjusted for population stratification using the top four principal components as derived from genome-wide SNP genotype data[31] using EIGENSTRAT (EIGENSOFT Version 2.0)[26]. SAS version 9.1 (SAS Institute, Cary, NC)was used to manage and analyze the data. We calculated a combined $\mathrm{p}$ value (first for all three cohorts and then for the two cohorts of children) using Fisher's exact test $[32,33]$.

\section{Transient transfection and luciferase assay}

Two TLR9 promoter sequences (from -632 to +619 ) including the SNP of interest (-1237C/T or rs5743836) were amplified by PCR from human genomic DNA and cloned into a pGL3 basic vector at a KpnI and HindIII site. The primers used for PCR were: 5' - GGG GTA CCC CGA GGG GTC ATA TGA GAC TTG GGG GAG TTT TCA - 3' for the 1.2KT and 5'-GGG GTA CCC CGA GGG GTC ATA TGA GAC TTG GGG GAG TTT CCA-3' for the1.2KC promoter. The same reverse primer for both promoters was used: $5^{\prime}$ - CCC AAG CTT GCT GGG CTT CTC CAG AGG GT - 3'. For the luciferase reporter assay, 293 cells were seeded into a 12-well plate one day prior to transfection. $300 \mathrm{ng}$ promoter or pGL3 basic vector and $10 \mathrm{ng}$ betagal plasmid were transiently transfected into 293 cells using Fugene 6 (Roche Diagnostics, Indianapolis, IN) according to the manufacturer's protocol. 12 hours post transfection, 1,25-dihydroxyitamin $\mathrm{D}_{3}$ (Enzo Life Sciences, Farmingdale, NY) was added into cells at various concentrations for an additional 48 hours. Cells were then lysed in $100 \mathrm{ul}$ reporter lysis buffer (Promega, Madison, WI) and the luciferase activity in $50 \mathrm{ul}$ of aliquots of cell lysates was measured using Luciferase Assay System (Promega, Madison, WI) according to the manufacturer's protocol. To monitor the transfection efficiency, a beta-galactosidase assay was conducted using the same lysate according to the published protocol[34]. All constructs were sequenced before transfection and each experiment was independently repeated four times with triplicate wells for each transfection reaction.

\section{Results}

\section{TLR9 promoter polymorphism genotyping}

The TLR9 promoter region SNP rs5743836 was genotyped in 910 families ( $\mathrm{n}=2261$ subjects) in CAMP, in 616 families ( $\mathrm{n}=1737$ subjects) in Costa Rica, and in 1081 subjects from iCAP (223 cases, 858 controls). In 
CAMP, the genotype quality was high, with a $99.4 \%$ completion rate, only one parent-child genotype inconsistency, and perfect concordance upon replicate genotyping of a random $5 \%$ subset. In Costa Rica and iCAP, genotype quality was also high with a $98 \%$ overall pass rate, perfect concordance upon replicate genotyping of a random 6\% subset and only 1 discordant result.

Given the relatively small sample sizes of the nonwhite ethnic groups in CAMP and to avoid false association caused by population stratification, association analyses were restricted to 711 Caucasian probands and their families. Phenotypic characteristics of the Caucasian children from CAMP as well as baseline characteristics of the Costa Rica cohort and iCAP cohorts are shown in Table 1. The minor allele frequency (MAF) for the $\mathrm{C}$ allele was $18 \%$ in CAMP, $10 \%$ in Costa Rica and $15 \%$ in iCAP. In all three cohorts parental or control genotypes were in Hardy-Weinberg equilibrium at this locus $($ CAMP $\mathrm{p}=0.29, \mathrm{CR} \mathrm{p}=0.78, \mathrm{iCAP} \mathrm{p}=0.27)$.

\section{Association testing of TLR9 promoter region polymorphism and asthma}

Though there was a trend towards over-transmission of the minor allele $(\mathrm{C})$ from parent to asthmatic offspring in the CAMP cohort, (transmitted to untransmitted ratio [T:U] of 136:112, ratio of 1.21 for the $C$ allele), the association was not statistically significant (FBAT $\mathrm{p}=0.14$ ). There was no trend towards an association in either Costa Rica (FBAT p $=0.77)$ or $\mathrm{iCAP}\left(\chi^{2} \mathrm{p}=0.83\right)$; see Table 2. Using Fisher's exact test, we calculated a combined $\mathrm{p}$ value first for all three cohorts together, and separately for the two childhood cohorts; neither of these values was statistically significant $(\mathrm{p}=0.57$ for all three, $\mathrm{p}=0.35$ for the two childhood cohorts).
Table 2 Results for association testing with rs5743836 and asthma affection status

\begin{tabular}{rcc}
\hline Cohort & Sample size $^{\mathbf{1}}$ & p value $^{\mathbf{2}}$ \\
\hline CAMP & 208 & 0.14 \\
Costa Rica & 185 & 0.77 \\
iCAP cohort & cases: 223 ctrls: 858 & 0.83 \\
\hline
\end{tabular}

${ }^{1}$ Number of informative families in CAMP and Costa Rica; $\mathrm{N}$ for iCAP.

${ }^{2}$ FBAT in CAMP and Costa Rica, chi-square test in iCAP.

Moreover, with the exception of post-bronchodilator measures of lung function (see below), no associations were noted with intermediate phenotypes analyzed in CAMP - including bronchodilator response to albuterol, airways responsiveness, total IgE, skin prick tests for common aeroallergens, and blood eosinophil counts suggesting that TLR9 genotype is not a major determinant of asthma in the CAMP cohort.

Association of TLR9 was noted with post-bronchodilator lung function measures $\left(\mathrm{FEV}_{1}\right.$ and $\left.\mathrm{FVC}\right)$ at the 4-year follow-up time point in CAMP, with each additional copy of the minor allele associated with higher lung function $(\mathrm{p}=0.003$ and $\mathrm{p}=0.008$, respectively). The observed associations were robust to multivariate adjustment for age, height, sex and treatment arm. Similar nominal associations were noted when modeled using population-based approaches $(\mathrm{p}=0.009$ and $p=0.01$, respectively; Figure 1). However, neither the family- nor population-based tests were significant after adjustment for multiple comparisons, and the small actual difference in values was of uncertain clinical significance. Associations were noted only with year 4 measurements, but not with baseline measures, and were not replicated in the Costa Rica cohort (data not shown) raising questions about the importance of

Table 1 Baseline characteristics in each cohort

\begin{tabular}{|c|c|c|c|c|c|}
\hline & CAMP & Costa Rica & & iCAP & \\
\hline & \multicolumn{5}{|c|}{ Mean (SD) } \\
\hline & & & Cases & & Controls \\
\hline$\overline{\mathrm{N}}$ & 711 & 616 & 223 & & 858 \\
\hline Age & $8.8(2.1)$ & $9.0(1.8)$ & $25.5(7.0)$ & & $26.1(5.3)$ \\
\hline $\operatorname{Sex}(N, \%$ male $)$ & $416(59 \%)$ & $370(60 \%)$ & $43(19 \%)$ & & $136(16 \%)$ \\
\hline Baseline post-bronchodilator $\mathrm{FEV}_{1}$ & $1.82(0.5)$ & $1.83(0.5)$ & & & \\
\hline baseline post-bronchodilator $\mathrm{FEV}_{1}$ percent-predicted & 104 (12.6) & $104(16.1)$ & & & \\
\hline Baseline post-bronchodilator FVC & $2.15(0.63)$ & $2.14(0.57)$ & & & \\
\hline Baseline post-bronchodilator FVC percent-predicted & 107 (12.6) & $109(15.8)$ & & & \\
\hline Post-bronchodilator $\mathrm{FEV}_{1}$ at $4 \mathrm{yr}$ follow up & $2.79(0.79)$ & & & & \\
\hline Post-bronchodilator $\mathrm{FEV}_{1}$ at $4 \mathrm{yr}$ follow up percent predicted & $103(12.6)$ & & & & \\
\hline Post-bronchodilator FVC at $4 \mathrm{yr}$ follow up & $3.35(0.98)$ & & & & \\
\hline Post-bronchodilator FVC at 4 yr follow up percent predicted & $107(12.2)$ & & & & \\
\hline \multicolumn{6}{|l|}{ rs5743836 C: minor allele T: major allele } \\
\hline Minor allele frequency & $18 \%$ & $10 \%$ & & $15 \%$ & \\
\hline
\end{tabular}




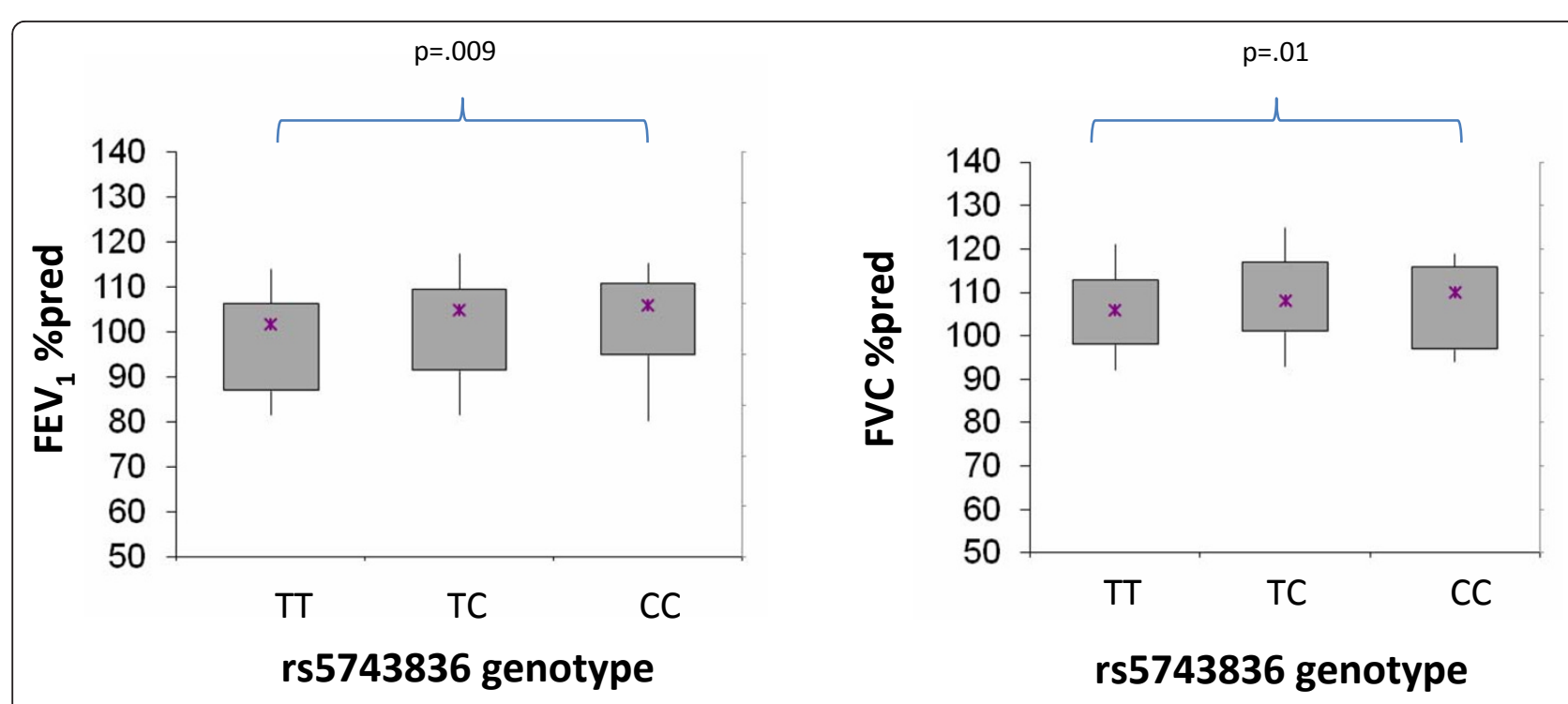

Figure 1 Results from population-based analysis of rs5743836 genotype and lung function measures in CAMP. Median values (X) and interquartile range for $\mathrm{FEV}_{1}$ and $\mathrm{FVC}$ at the 4 year follow up timepoint by rs5743836 genotype in CAMP.

the observed associations. Moreover, the TLR9 promoter variant was not associated with asthma exacerbations over the 4 years of the clinical trial (defined as emergency room visits, hospitalizations or prednisone bursts).

\section{Interaction with Vitamin D}

Based on prior knowledge of the interaction of TLR9 with vitamin $\mathrm{D}[12]$, and the relationship to induction of IL-10 producing Tregs, we tested for an interaction between the SNP and vitamin D levels in this cohort. We did not find a significant association with this SNP and vitamin D insufficiency (defined as $\leq 30 \mathrm{ng} / \mathrm{ml}$ ) with any lung function measures $(\mathrm{p}=0.44-0.98$ for interaction), nor with the other outcomes tested including those listed above. We looked at vitamin D levels as a continuous variable as well and found similar results (data not shown).

\section{Functional studies of TLR9 promoter region genotype}

To test whether rs5743836 genotype affects promoter activity of the TLR9 gene, we cloned two promoters containing either the TT or CC genotype into firefly luciferase reporter vectors; the two promoters were designated as $1.2 \mathrm{KT}$ and $1.2 \mathrm{KC}$ respectively. Promoter activity was assessed using the luciferase assay system. After standardization with beta-gal, the promoter containing the $\mathrm{T}$ variant $(1.2 \mathrm{KT})$ showed lower activity than the promoter containing the $\mathrm{C}$ variant $(9.3$ fold versus 11.7 fold, $\mathrm{P}=0.003$ )

(Figure 2A). We further investigated whether the active form of vitamin $\mathrm{D}\left(1,25(\mathrm{OH})_{2} \mathrm{D}_{3}\right)$ affects promoter activity of TLR9. After 2 days of treatment with 1,25 $(\mathrm{OH})_{2} \mathrm{D}_{3}$, the change of TLR9 promoter activity was negligible in 293 cells (Figure 2B).

Because the $\mathrm{CC}$ genotype was associated with higher promoter activity, we analyzed TLR9 mRNA expression levels from CD4+ lymphocytes from a subset of 200 non-Hispanic white CAMP asthmatics. Expression levels were not significantly associated with rs5743836 genotype (FBAT $\mathrm{p}=0.80$, populationbased $\mathrm{p}=0.38$ ).

\section{Discussion}

Based on previous studies by our group[5], and knowledge of a potential interaction between TLR9 and vitamin $\mathrm{D}[12,35]$, we examined possible associations between rs5743836, a SNP in the promoter region of TLR9, and asthma in three different cohorts of asthmatics, as well as with related quantitative phenotypes in the CAMP cohort. We also looked for an interaction between this SNP and vitamin D levels, and performed functional studies using this SNP. Although there was a trend towards over transmission of the $\mathrm{C}$ allele in children with asthma in the CAMP cohort, this was not statistically significant; nor was it found in the other two cohorts of asthmatics. We found a weak association between this SNP and lung function measures in CAMP at the 4-year follow-up point in both the family-and population-based analyses. However this was no longer statistically significant once corrected for multiple comparisons, was only observed at one of two time points studied, and was not replicated in the Costa Rican cohort. We found no other significant associations 


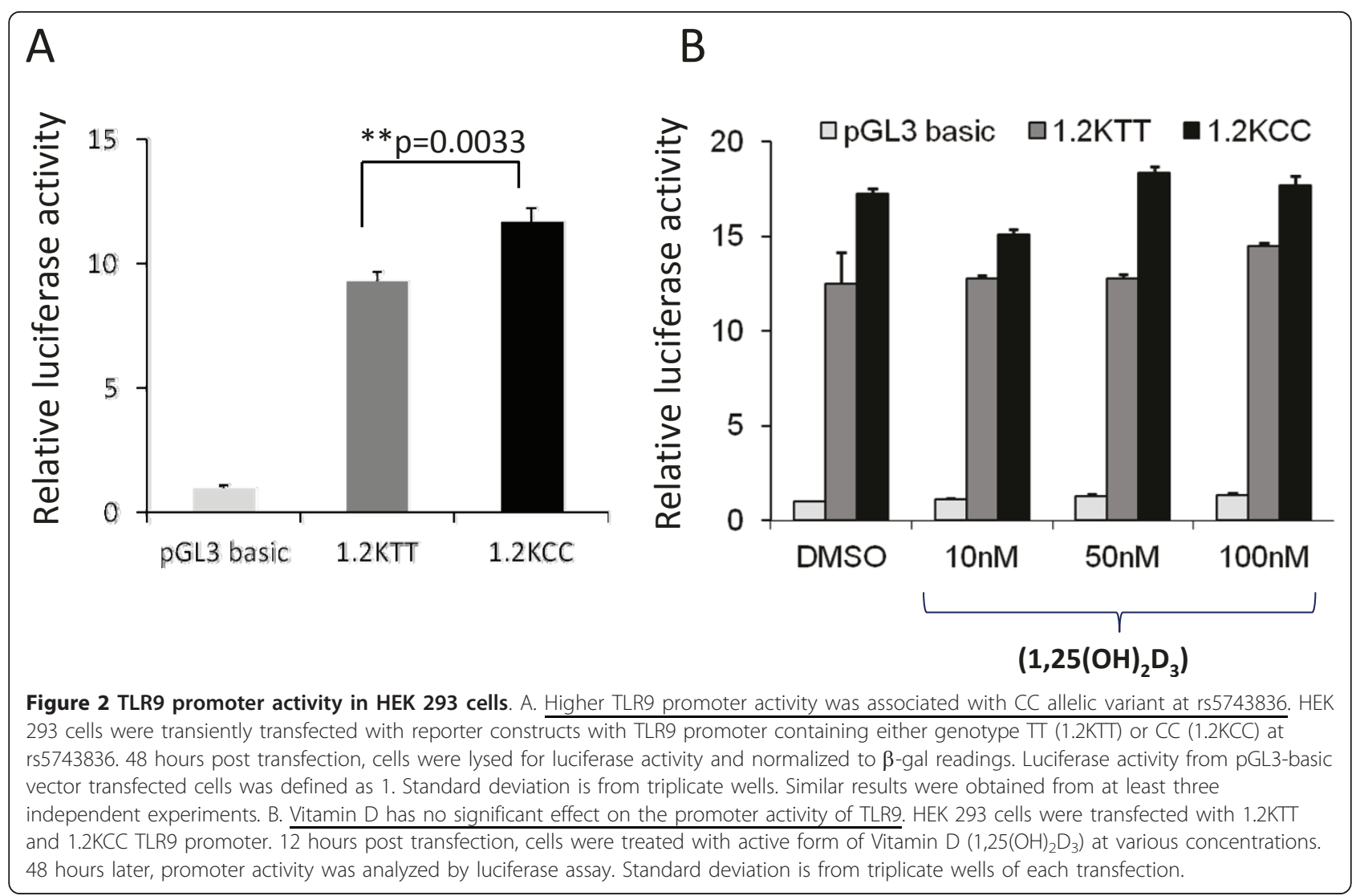

between this SNP and any other intermediate phenotypes tested, nor was there an interaction with vitamin $\mathrm{D}$ levels. Though we demonstrated in vitro evidence that the rs5743836 CC genotype confers increased expression of TLR9, this association was not observed in an epidemiological context: the variant was not associated with CD4+ lymphocyte TLR9 expression in the CAMP cohort. Together, these data suggest this polymorphism does not play a role in susceptibility to asthma in these three cohorts, nor in the development of asthma-related phenotypes in CAMP.

Evidence from prior studies suggests that this SNP in TLR9 could be important in asthma and other inflammatory diseases. Our group had previously found the $\mathrm{C}$ allele of this SNP to be associated with asthma in European Americans[5]. Another study showed similar findings in a cohort of Tunisian children with asthma, with higher risk conferred by the C allele[6]. The SNP has been found to be associated with other allergic diseases such as ABPA in a population from the UK[7]; one of the diagnostic criteria for ABPA is the presence of asthma. An association was also found in a study of atopic eczema in Germans[8], though it was the $\mathrm{T}$ allele that was over transmitted in affected individuals. In addition, it has been found in association with IBD [9-11,36] as well as with Hodgkin's disease[37] susceptibility to tuberculosis infection[38] and viral set point in HIV[39].

Furthermore, other emerging data about TLR9 more generally offers compelling evidence for its role in modulation of inflammatory and allergic diseases, and a possible route to therapy. TLR9 knockout mice have lower airways hyperresponsiveness in a model of fungal asthma[40]. Additionally, the ligand for TLR9 (CpG) is being investigated in animal models and some human studies as an adjuvant for immunotherapy of allergic diseases including allergic rhinitis and asthma[3,41-43]. Although the exact mechanism of benefit is unknown, the inhibition of $\mathrm{TH} 2$ cytokines may be achieved through induction of TH1-type cytokines such as IL12, IFN $\alpha$, IFN $\gamma$, or through other mechanisms $[44,45]$ including induction of IL-10 or indoleamine 2,3-dioxygenase activity and Treg cells[46,47]. The biologic effects of TLR9 activation on allergic inflammation are likely highly complex and merit further investigation.

However, conflicting studies showed no association with this SNP or others in TLR9 in similar diseases. No association was found with atopy in a second German cohort[48]. The rs5743836 polymorphism was not observed in a sequencing survey of 32 Japanese asthmatics. Other TLR9 variants that were observed in that cohort showed no associations with asthma affection 
status or serum IgE level[49]. Similar studies in Caucasian populations from Canada and Australia[50], and in French Europeans[51] also failed to observe associations with asthma. TLR9 variation does not appear to have association with either SLE[52-54] or Behcet's disease $[55,56]$.

The strengths of our study include the use of three different asthmatic populations: two in children and one in adults. In addition, our analysis of intermediate phenotypes was carried out in CAMP, a well-characterized population of asthmatics with extensive phenotyping data including lung function measures (spirometry, methacholine challenge results, bronchodilator responsiveness), skin test results, IgE and eosinophil levels, and data on exacerbation frequency. We used both a familybased association test, which is robust to population stratification, as well as population-based testing, which is more powerful than family-based testing. Population based tests were adjusted for population stratification using principal components[26]. The addition of a high quality assessment of functionality with this SNP strengthens any possibility of association.

There are several possible reasons for discrepant results among studies of association between this SNP and asthma. These include sample size, differing phenotype definitions, differing populations, population stratification, differing linkage disequilibrium patterns, and genetic and environmental heterogeneity. Our study includes two well-characterized cohorts of children with asthma, and a cohort of adult asthmatics. Asthmatics of differing severity or age may be a different enough phenotype to lead to different results from association testing. We may have been limited in power to detect an association given the sample sizes in the three cohorts. In addition, the population-based association testing performed in CAMP examined variability among individuals within the cohort of asthmatics; if we had compared our cohort to a well-matched control group, testing intermediate phenotypes may have revealed an association. Prior studies of this SNP and asthma were small and were not controlled for population stratification. In the Tunisian study, significant results from the case-control analysis were not reproduced when families were analyzed using the transmission disequilibrium test (TDT) which is robust to population stratification, suggesting positive results from the case-control portion may have been spurious.

We detected a moderate increase in promoter activity associated with the CC genotype. This could be explained by the possible creation of an NF- $\kappa$ B binding site due to a change to the $\mathrm{C}$ allele which has been shown in in silico analysis[57]. Higher promoter activity with the $\mathrm{T}$ allele has been found in one previous study [8] though more recently another study showed higher activity with the $\mathrm{C}$ allele, consistent with our findings [58]. Since we found no correlation between rs5743836 genotype and TLR9 mRNA level in a subset of the CAMP population, we cannot exclude the existence of other functional variants in this region that interact with rs5743836 to regulate the expression of TLR9. Given the complexity of gene regulation in vivo, the lack of association with TLR9 expression levels is not surprising.

\section{Conclusions}

In summary, we examined associations between a SNP in the promoter of TLR9, rs5743836, and asthma in three unrelated cohorts of asthmatics, and found no statistically significant associations after correcting for multiple testing. In addition, we performed functional studies which showed that this SNP does appear to have functional significance. Despite these in vitro findings, our results suggest that this polymorphism does not play a significant role in asthma susceptibility or asthma related phenotypes. This does not rule out a role for the gene in asthma. Despite these negative results, future studies to further elucidate the effects of TLR9 activation in modulating inflammation, as well as the possible role of TLR9 agonists in therapy for allergic and inflammatory diseases are warranted.

\section{Funding}

CAMP: The CAMP Genetics Ancillary Study is supported by U01 HL075419, U01 HL65899, P01 HL083069 and T32 HL07427 from the National Heart, Lung and Blood Institute, National Institutes of Health (NIH/NHLBI). The expression work is supported by grant R01 HL086601 from the (NIH/NHLBI). Dr. Litonjua is supported by R01 AI056230. Dr. Lazarus is supported by R01 HG0036.

Costa Rica: The Genetics of Asthma in Costa Rica study is supported by NIH grants HL04370 and HL66289.

iCAP: This work was supported by the NIH grant 5U54LM008748-02 (National Centers for Biomedical Computing).

\section{Acknowledgements}

We thank all subjects and their families for their past and ongoing participation in the CAMP and the Genetics of Asthma in Costa Rica studies. We acknowledge the CAMP investigators and research team, supported by $\mathrm{NHLBI}$, for collection of CAMP Genetic Ancillary Study data. We thank Drs. Andy Liu and Stanley Szefler (National Jewish, Denver CO), Nadia Hansel, Greg Diette and Franklin Adkinson (Johns Hopkins, Baltimore MD), and Karen DeMuth, Robert Strunk and Mario Castro (Washington University, St. Louis $\mathrm{MO}$ ) and Anne Fuhlbrigge (Brigham and Women's Hospital, Boston MA) for their assistance in collection of CD4+ lymphocytes and RNA extraction. Special thanks to Anne Plunkett, Teresa Concordia, Debbie Bull, Denise Rodgers, and D. Sundstrom for their assistance with sample collection; to Huiqing Yin-DeClue, Ph.D, Michael McLane and Chris Allaire for their assistance with T cell isolations and RNA preparation; and to Ankur Patel for his assistance running the microarrays. 
All work on data collected from the CAMP Genetic Ancillary Study and the Costa Rica study was conducted at the Channing Laboratory of the Brigham and Women's Hospital under appropriate policies and human subject protections.

We thank Scott Weiss for his advice in the preparation of this manuscript.

\section{Author details}

${ }^{1}$ Channing Laboratory, Brigham and Women's Hospital and Harvard Medical School, 181 Longwood Avenue, Boston, MA, 02115, USA. ²Division of Pulmonary and Critical Care Medicine, Brigham and Women's Hospital and Harvard Medical School, 75 Francis Street, Boston, MA, 02115, USA. ${ }^{3}$ Division of Pediatric Pulmonology, Hospital Nacionál de Niños, Calle 20, San José, Costa Rica. ${ }^{4}$ Division of Pediatric Pulmonary Medicine, Allergy and Immunology, Children's Hospital of Pittsburgh of the University of Pittsburgh Medical Center, One Children's Hospital Drive, 4401 Penn Ave., Pittsburgh, PA, 15224, USA. 'Department of Asthma, Allergy and Respiratory Science, King's College London, Guy's Hospital, Great Maze Pond, London SE1 9RT, UK.

\section{Authors' contributions}

NEL contributed to the study design, performed the analyses and drafted the manuscript. XZ performed the functional studies and contributed to the manuscript writing. JL-S contributed to the study design and statistical analysis. BEH contributed to the statistical analysis. RL contributed to the statistical analysis. MSQ contributed to the study design and data collection. LA contributed to the study design and data collection. JCC contributed to the study design and provided critical revision of the manuscript. $\mathrm{CMH}$ contributed to the data analysis and interpretation. BAR contributed to the study design and provided critical revision of the manuscript. AAL contributed to the study design and provided critical revision of the manuscript. All authors read and approved the final manuscript.

\section{Competing interests}

Dr. Soto-Quiros reports receiving lecture fees from AstraZeneca, GlaxoSmithKline, and Merck Sharp \& Dohme; Dr. Avila reports receiving lecture fees from AstraZeneca and Merck Sharp \& Dohme; Dr. Hawrylowicz reports receiving lecture honoraria/fees from Merck. Dr. Raby reports receiving lecture fees from Novartis Pharmaceuticals for in-house educational services. No other authors have any competing interests to declare.

Received: 4 August 2010 Accepted: 15 February 2011

Published: 15 February 2011

\section{References}

1. Masoli M, Fabian D, Holt S, Beasley R: The global burden of asthma: executive summary of the GINA Dissemination Committee report. Allergy 2004, 59(5):469-478.

2. Schroder NW, Maurer M: The role of innate immunity in asthma: leads and lessons from mouse models. Allergy 2007, 62(6):579-590.

3. Krieg AM: Therapeutic potential of Toll-like receptor 9 activation. Nat Rev Drug Discov 2006, 5(6):471-484.

4. Pasare C, Medzhitov R: Control of B-cell responses by Toll-like receptors. Nature 2005, 438(7066):364-368.

5. Lazarus R, Klimecki WT, Raby BA, Vercelli D, Palmer LJ, Kwiatkowski DJ, Silverman EK, Martinez F, Weiss ST: Single-nucleotide polymorphisms in the Toll-like receptor 9 gene (TLR9): frequencies, pairwise linkage disequilibrium, and haplotypes in three U.S. ethnic groups and exploratory case-control disease association studies. Genomics 2003, 81(1):85-91.

6. Lachheb J, Dhifallah IB, Chelbi H, Hamzaoui K, Hamzaoui A: Toll-like receptors and CD14 genes polymorphisms and susceptibility to asthma in Tunisian children. Tissue Antigens 2008, 71(5):417-425.

7. Carvalho A, Pasqualotto AC, Pitzurra L, Romani L, Denning DW, Rodrigues F: Polymorphisms in toll-like receptor genes and susceptibility to pulmonary aspergillosis. J Infect Dis 2008, 197(4):618-621.

8. Novak N, Yu CF, Bussmann C, Maintz L, Peng WM, Hart J, Hagemann T, Diaz-Lacava A, Baurecht HJ, Klopp N, et al: Putative association of a TLR9 promoter polymorphism with atopic eczema. Allergy 2007, 62(7):766-772
9. Hong J, Leung E, Fraser AG, Merriman TR, Vishnu P, Krissansen GW: TLR2, TLR4 and TLR9 polymorphisms and Crohn's disease in a New Zealand Caucasian cohort. J Gastroenterol Hepatol 2007, 22(11):1760-1766.

10. Torok HP, Glas J, Endres I, Tonenchi L, Teshome MY, Wetzke M, Klein W, Lohse P, Ochsenkuhn T, Folwaczny M, et al: Epistasis Between Toll-Like Receptor-9 Polymorphisms and Variants in NOD2 and IL23R Modulates Susceptibility to Crohn's Disease. Am J Gastroenterol 2009.

11. Torok HP, Glas J, Tonenchi L, Bruennler G, Folwaczny M, Folwaczny C: Crohn's disease is associated with a toll-like receptor-9 polymorphism. Gastroenterology 2004, 127(1):365-366.

12. Urry Z, Xystrakis E, Richards DF, McDonald J, Sattar Z, Cousins DJ, Corrigan CJ, Hickman E, Brown Z, Hawrylowicz CM: Ligation of TLR9 induced on human IL-10-secreting Tregs by 1alpha,25-dihydroxyvitamin D3 abrogates regulatory function. J Clin Invest 2009, 119(2):387-398.

13. Moore KW, de Waal Malefyt R, Coffman RL, O'Garra A: Interleukin-10 and the interleukin-10 receptor. Annu Rev Immunol 2001, 19:683-765.

14. The Childhood Asthma Management Program (CAMP): design, rationale, and methods. Childhood Asthma Management Program Research Group. Control Clin Trials 1999, 20(1):91-120.

15. Long-term effects of budesonide or nedocromil in children with asthma. The Childhood Asthma Management Program Research Group. N Engl J Med 2000, 343(15):1054-1063.

16. Miller MR, Hankinson J, Brusasco V, Burgos F, Casaburi R, Coates A, Crapo R, Enright $P$, van der Grinten CP, Gustafsson P, et al: Standardisation of spirometry. Eur Respir J 2005, 26(2):319-338.

17. Hollis BW, Kamerud JQ, Selvaag SR, Lorenz JD, Napoli JL: Determination of vitamin D status by radioimmunoassay with an 125 l-labeled tracer. Clin Chem 1993, 39(3):529-533.

18. Hollis BW, Napoli JL: Improved radioimmunoassay for vitamin D and its use in assessing vitamin D status. Clin Chem 1985, 31(11):1815-1819.

19. Hunninghake GM, Soto-Quiros ME, Avila L, Ly NP, Liang C, Sylvia JS, Klanderman BJ, Silverman EK, Celedon JC: Sensitization to Ascaris lumbricoides and severity of childhood asthma in Costa Rica. J Allergy Clin Immunol 2007, 119(3):654-661.

20. Pearce N, Ait-Khaled N, Beasley R, Mallol J, Keil U, Mitchell E, Robertson C: Worldwide trends in the prevalence of asthma symptoms: phase III of the International Study of Asthma and Allergies in Childhood (ISAAC). Thorax 2007, 62(9):758-766.

21. Blumenthal MN, Banks-Schlegel S, Bleecker ER, Marsh DG, Ober C: Collaborative studies on the genetics of asthma-National Heart, Lung and Blood Institute. Clin Exp Allergy 1995, 25(Suppl 2):29-32.

22. Himes BE, Dai Y, Kohane IS, Weiss ST, Ramoni MF: Prediction of chronic obstructive pulmonary disease (COPD) in asthma patients using electronic medical records. J Am Med Inform Assoc 2009, 16(3):371-379.

23. Zeng QT, Goryachev S, Weiss S, Sordo M, Murphy SN, Lazarus R: Extracting principal diagnosis, co-morbidity and smoking status for asthma research: evaluation of a natural language processing system. BMC Med Inform Decis Mak 2006, 6:30.

24. Pritchard JK, Rosenberg NA: Use of unlinked genetic markers to detect population stratification in association studies. Am J Hum Genet 1999, 65(1):220-228.

25. Price AL, Butler J, Patterson N, Capelli C, Pascali VL, Scarnicci F, RuizLinares A, Groop L, Saetta AA, Korkolopoulou P, et al: Discerning the ancestry of European Americans in genetic association studies. PLOS Genet 2008, 4(1):e236.

26. Price AL, Patterson NJ, Plenge RM, Weinblatt ME, Shadick NA, Reich D: Principal components analysis corrects for stratification in genome-wide association studies. Nat Genet 2006, 38(8):904-909.

27. Chu JH, Weiss ST, Carey VJ, Raby BA: A graphical model approach for inferring large-scale networks integrating gene expression and genetic polymorphism. BMC Syst Biol 2009, 3:55.

28. Lange C, DeMeo D, Silverman EK, Weiss ST, Laird NM: PBAT: tools for family-based association studies. Am J Hum Genet 2004, 74(2):367-369.

29. Lake SL, Laird NM: Tests of gene-environment interaction for case-parent triads with general environmental exposures. Ann Hum Genet 2004, 68(Pt 1):55-64.

30. Purcell S, Neale B, Todd-Brown K, Thomas L, Ferreira MA, Bender D, Maller J, Sklar P, de Bakker PI, Daly MJ, et al: PLINK: a tool set for whole-genome association and population-based linkage analyses. Am J Hum Genet 2007, 81(3):559-575. 
31. Himes BE, Hunninghake GM, Baurley JW, Rafaels NM, Sleiman P, Strachan DP, Wilk JB, Willis-Owen SA, Klanderman B, Lasky-Su J, et al: Genome-wide association analysis identifies PDE4 D as an asthmasusceptibility gene. Am J Hum Genet 2009, 84(5):581-593.

32. Fisher RAS: Statistical Methods for Research Workers. New York: Hafner Press; 141970.

33. Won S, Morris N, Lu Q, Elston RC: Choosing an optimal method to combine P-values. Stat Med 2009, 28(11):1537-1553.

34. Baron RM, Carvajal IM, Liu X, Okabe RO, Fredenburgh LE, Macias AA, Chen YH, Ejima K, Layne MD, Perrella MA: Reduction of nitric oxide synthase 2 expression by distamycin A improves survival from endotoxemia. J Immunol 2004, 173(6):4147-4153.

35. Dickie LJ, Church LD, Coulthard LR, Mathews RJ, Emery P, McDermott MF: Vitamin D3 down-regulates intracellular Toll-like receptor 9 expression and Toll-like receptor 9-induced IL-6 production in human monocytes. Rheumatology (Oxford) 2010.

36. Lammers KM, Ouburg S, Morre SA, Crusius JB, Gionchett P, Rizzello F, Morselli C, Caramelli E, Conte R, Poggioli G, et al: Combined carriership of TLR9-1237C and CD14-260T alleles enhances the risk of developing chronic relapsing pouchitis. World J Gastroenterol 2005, 11(46):7323-7329.

37. Mollaki V, Georgiadis T, Tassidou A, loannou M, Daniil Z, Koutsokera A, Papathanassiou AA, Zintzaras E, Vassilopoulos G: Polymorphisms and haplotypes in TLR9 and MYD88 are associated with the development of Hodgkin's lymphoma: a candidate-gene association study. J Hum Genet 2009.

38. Velez DR, Wejse C, Stryjewski ME, Abbate E, Hulme WF, Myers JL, Estevan R, Patillo SG, Olesen R, Tacconelli A, et al: Variants in toll-like receptors 2 and 9 influence susceptibility to pulmonary tuberculosis in Caucasians, African-Americans, and West Africans. Hum Genet 2009.

39. Pine SO, McElrath MJ, Bochud PY: Polymorphisms in toll-like receptor 4 and toll-like receptor 9 influence viral load in a seroincident cohort of HIV-1-infected individuals. AIDS 2009, 23(18):2387-2395.

40. Ramaprakash H, Ito T, Standiford TJ, Kunkel SL, Hogaboam CM: Toll-like receptor 9 modulates immune responses to Aspergillus fumigatus conidia in immunodeficient and allergic mice. Infect Immun 2009, 77(1):108-119.

41. Creticos PS, Schroeder JT, Hamilton RG, Balcer-Whaley SL, Khattignavong AP, Lindblad R, Li H, Coffman R, Seyfert V, Eiden JJ, et al: Immunotherapy with a ragweed-toll-like receptor 9 agonist vaccine for allergic rhinitis. N Engl J Med 2006, 355(14):1445-1455.

42. Kline JN, Krieg AM: Toll-like receptor 9 activation with CpG oligodeoxynucleotides for asthma therapy. Drug News Perspect 2008, 21(8):434-439.

43. Kanzler H, Barrat FJ, Hessel EM, Coffman RL: Therapeutic targeting of innate immunity with Toll-like receptor agonists and antagonists. Nat Med 2007, 13(5):552-559.

44. Kline JN, Krieg AM, Waldschmidt TJ, Ballas ZK, Jain V, Businga TR: CpG oligodeoxynucleotides do not require $\mathrm{TH} 1$ cytokines to prevent eosinophilic airway inflammation in a murine model of asthma. J Allergy Clin Immunol 1999, 104(6):1258-1264.

45. Tversky JR, Bieneman AP, Chichester KL, Hamilton RG, Schroeder JT: Subcutaneous allergen immunotherapy restores human dendritic cell innate immune function. Clin Exp Allergy 40(1):94-102.

46. Constabel H, Stankov MV, Hartwig C, Tschernig T, Behrens GM: Impaired lung dendritic cell migration and $T$ cell stimulation induced by immunostimulatory oligonucleotides contribute to reduced allergic airway inflammation. J Immunol 2009, 183(5):3443-3453.

47. Kline JN: Eat dirt: CpG DNA and immunomodulation of asthma. Proc Am Thorac Soc 2007, 4(3):283-288.

48. Berghofer B, Frommer T, Konig IR, Ziegler A, Chakraborty T, Bein G, Hackstein H: Common human Toll-like receptor 9 polymorphisms and haplotypes: association with atopy and functional relevance. Clin Exp Allergy 2005, 35(9):1147-1154.

49. Noguchi E, Nishimura F, Fukai H, Kim J, Ichikawa K, Shibasaki M, Arinami T: An association study of asthma and total serum immunoglobin $E$ levels for Toll-like receptor polymorphisms in a Japanese population. Clin Exp Allergy 2004, 34(2):177-183.

50. Daley $D$, Lemire $M$, Akhabir L, Chan-Yeung M, He JQ, McDonald T, Sandford A, Stefanowicz D, Tripp B, Zamar D, et al: Analyses of associations with asthma in four asthma population samples from Canada and Australia. Hum Genet 2009, 125(4):445-459.
51. Smit LA, Siroux V, Bouzigon E, Oryszczyn MP, Lathrop M, Demenais F, Kauffmann F: CD14 and toll-like receptor gene polymorphisms, country living, and asthma in adults. Am J Respir Crit Care Med 2009, 179(5):363-368.

52. De Jager PL, Richardson A, Vyse TJ, Rioux JD: Genetic variation in toll-like receptor 9 and susceptibility to systemic lupus erythematosus. Arthritis Rheum 2006, 54(4):1279-1282.

53. Demirci FY, Manzi S, Ramsey-Goldman R, Kenney M, Shaw PS, DunlopThomas CM, Kao AH, Rhew EY, Bontempo F, Kammerer C, et al: Association study of Toll-like receptor 5 (TLR5) and Toll-like receptor 9 (TLR9) polymorphisms in systemic lupus erythematosus. J Rheumatol 2007, 34(8):1708-1711.

54. Hur JW, Shin HD, Park BL, Kim LH, Kim SY, Bae SC: Association study of Toll-like receptor 9 gene polymorphism in Korean patients with systemic lupus erythematosus. Tissue Antigens 2005, 65(3):266-270.

55. Ito A, Ota M, Katsuyama Y, Inoko H, Ohno S, Mizuki N: Lack of association of Toll-like receptor 9 gene polymorphism with Behcet's disease in Japanese patients. Tissue Antigens 2007, 70(5):423-426.

56. Ben Dhifallah I, Lachheb J, Houman H, Hamzaoui K: Toll-like-receptor gene polymorphisms in a Tunisian population with Behcet's disease. Clin Exp Rheumatol 2009, 27(2 Suppl 53):S58-62.

57. Hamann L, Glaeser C, Hamprecht A, Gross M, Gomma A, Schumann RR: Toll-like receptor (TLR)-9 promotor polymorphisms and atherosclerosis. Clin Chim Acta 2006, 364(1-2):303-307.

58. Ng MT, van 't Hof R, Crockett JC, Hope ME, Berry S, Thomson J, McLean MH, McColl KE, El-Omar EM, Hold GL: Increase in NF-\{kappa\}B binding affinity of the $C$ allelic variant of the Toll-like receptor $9-1237 \mathrm{~T} /$ $C$ polymorphism is associated with Helicobacter pylori induced gastric disease. Infect Immun 2009.

\section{Pre-publication history}

The pre-publication history for this paper can be accessed here: http://www.biomedcentral.com/1471-2350/12/26/prepub

doi:10.1186/1471-2350-12-26

Cite this article as: Lange et al:: Comprehensive genetic assessment of a functional TLR9 promoter polymorphism: no replicable association with asthma or asthma-related phenotypes. BMC Medical Genetics 2011 12:26.

\section{Submit your next manuscript to BioMed Central and take full advantage of:}

- Convenient online submission

- Thorough peer review

- No space constraints or color figure charges

- Immediate publication on acceptance

- Inclusion in PubMed, CAS, Scopus and Google Scholar

- Research which is freely available for redistribution 